\title{
Analysis of Village Financial Management Accountable and Transparent
}

\author{
Meyulinda Aviana Elim*, Jasintha Dessy Tapatfeto \\ Accounting Department \\ State Polytechnic of Kupang \\ Kupang, Indonesia \\ *meyulinda.aviana@gmail.com, jasintha09@yahoo.com
}

\begin{abstract}
This research aimed to analyse village financial management, based on the principles of Financial Accountability and Transparency. This type of research is a case study with the research location in the village in South Amarasi District, Kupang Regency, East Nusa Tenggara. Research data obtained through interviews, observation and documentation. The data analysis technique used is descriptive qualitative analysis. Data from interviews, observations and documentation are compared with indicators that have been established with reference to government regulations. The variables analysed included village financial management, accountability, and transparency. The results showed that village financial management in 5 villages in Amarasi Selatan District, Kupang Regency, has followed Permendagri number 113 of 2014. In all stages of village financial management, all villages have met the principle of transparency, but still have not met the principle of accountability.
\end{abstract}

Keywords-village financial management, accountability, transparency

\section{INTRODUCTION}

Accountability and transparency are the keys to realizing a clean and honest government, including village government. With the issuance of Law Number 6 of 2014 [1] concerning Villages, it has authorized the Village Government as the smallest government unit to manage its finances independently. In financial management, villages need good control from the government above them, such as district / city governments, provincial governments, central government and from the community.

Based on the Regulation of the Minister of Home Affairs Number 20 of 2018 [2] as a substitute for the Minister of Home Affairs regulation number 113 of 2014 [3] concerning Village Financial Management states that village finance is all village rights and obligations that can be valued in money and everything in the form of money and money. goods related to the implementation of village rights and obligations, in addition to that village finances must be managed based on transparent, accountable, participatory principles, and carried out in an orderly manner and in a disciplined budget.
Until now, there are still many villages in Indonesia, including in East Nusa Tenggara that have not been able to manage villages, especially managing village finances in accordance with government regulations, such as Law Number 6 of 2014 and Permendagri Number 113 of 2014 (which has been revised through a Minister of Home Affairs Regulation Number 20 of 2018). The problem that often arises related to village financial management is that the implementation of village meetings is not optimal. Meanwhile, village meetings are one of the accesses for the community to obtain information about village financial management, and village deliberations are the responsibility of the village government in implementing Law number 6 of 2014 concerning Villages. This study aims to analyse financial management in villages in the South Amarasi sub-district, Kupang regency, East Nusa Tenggara based on the principles of financial accountability and transparency.

\section{LITERATURE REVIEW}

\section{A. Village Finance}

With the enactment of Law Number 6 of 2014 concerning Villages, what is of our common concern is how then the village government manages finances and is accountable for it. According to article 71 paragraph (1) of Law Number 6 of 2014, it is stated that Village Finance is the rights and obligations of the Village which can be valued in money and everything in the form of money and goods related to the implementation of the rights and obligations of the Village. Furthermore, in paragraph (2) it is stated that the existence of rights and obligations will generate income, expenditure, financing, and management of Village Finances. With the enactment of Government Regulation Number 43 of 2014 [4] concerning Implementation Regulations of Law Number 6 of 2014 concerning Villages, it has described what was previously regulated in Law Number 6 of 2014, including: Article 93 paragraph (1) states that management Village finance includes: planning, implementation, administration, reporting, and accountability. Based on Article 105, it is stated that the provisions regarding Village financial management will be regulated in a Ministerial Regulation. 
According to the Minister of Home Affairs Regulation Number 20 of 2018, Village Finance is all the rights and obligations of the Village which can be valued in money as well as everything in the form of money and goods related to the implementation of the rights and obligations of the Village.

\section{B. Accountability}

Accountability is the obligation to give accountability or answer and explain the performance and actions of a person / legal entity or leader of an organization to parties who have the right or authority to ask for information or accountability [5] Mardiasmo defines accountability as an obligation to report and be responsible for the success or failure of the implementation of the organization's mission in achieving predetermined results, through accountability media which is carried out regularly [6]. Broadly speaking, regarding the accountability explanation, it can be concluded that accountability is the responsibility of an institution that is authorized to manage public resources.

\section{Transparency}

According to Mardiasmo transparency is one of the fundamental aspects for the realization of good governance. The realization of good governance requires openness, involvement and easy access for the community to the process of government administration [6]. The openness and ease of information on governance has the effect of realizing various other indicators. Meanwhile Dwiyanto argues that transparency is the provision of information about government to the public and guarantees the ease of obtaining accurate and adequate information [7]. Based on the above definition, it can be concluded that transparency is providing open information regarding financial information as well as policies taken by the government and ensuring access for everyone or the public to obtain this information.

\section{Previous Research}

Subroto in his research on Village Fund Management Accountability with a Case Study of Village Fund Allocation Management in Villages Within the District of Tlogomulyo, Temanggung District, found that for planning and implementing Village Fund Allocation activities, it has shown that there is an accountable and transparent [8]. Meanwhile, in terms of accountability, physical results have shown accountable and transparent implementation, but from the administrative side, further guidance is still needed, because it is not fully in accordance with the provisions. The main obstacle is the ineffective development of village government officials and the competence of human resources, so that they still need assistance from local government officials on an ongoing basis. Meanwhile Muntahanah and Murdijaningsih in their research on the Effectiveness of Village Fund Allocation Financial Management in Somagede District, Banyumas Regency, found that Somagede District as the recipient of ADD funds is fully responsible for the implementation and reporting of ADD financial and its use for the benefit of the community [9]. ADD financial reporting in Somagede District from year to year has been running according to existing regulations

In his research on Comparative Analysis of Bangsri Village Financial Management According to Permendagri 37 of 2007, Ramadhan found that overall financial management in Bangsri Village was almost the same as management according to the format of Permendagri 37 of 2007 [10,11].

\section{RESEARCH METHOD}

\section{A. Object of Research}

This research is a field research by taking samples from 5 villages in South Amarasi Sub district, Kupang Regency, NTT Province

\section{B. Data Collection Technique}

The data in this study is obtained through: field observation, shooting in the field and results of interviews.

\section{Research Variable}

This study will examine 3 variables, namely:

1) Village financial management: Village financial management is measured through 5 stages (according to Permendagri number 20 of 2018), namely: planning; implementation; administration; reporting; and accountability.

2) Accountability variable: Accountability in the implementation of village government is defined as the obligation of the village government to be accountable for the management of village finances and the implementation of government in the village in the context of village autonomy to achieve the goals that have been set through accountability media that is measurable both in terms of quality and quantity. Accountability criteria: accountability for the use / use of funds, timely presentation, inspection / audit $[12,13]$.

3) Transparency variable: Transparency is very important in the implementation of government functions, especially in financial management where the government has a mandate from the people. The implementation of transparency in financial management which is the community's right, the village government will gain the trust of the community so that it is hoped that the community will be more obedient in carrying out their obligations so that sustainable development is created. Criteria for transparency: open accountability, accessibility to financial reports, publication of financial reports (audit results and performance information) [12,13].

\section{Data Analysis Technique}

This study uses descriptive qualitative data analysis techniques. The analysis was carried out by describing or describing in full and real terms the management of village finances with the principles of Accountability and Transparency in Villages in the South Amarasi District, 
Kupang Regency, NTT, with reference to the Minister of Home Affairs Regulation Number 20 of 2018.

The stages of the analysis are carried out as follows:

- Describe an overview of Village Financial Management in Amarasi Selatan District, Kupang Regency

- Describe the results of interviews, observations and documentation obtained regarding village financial management based on the principles of accountability and transparency.

- Analyse the results of interviews, observations and documentation that have been described, by looking at the following documents: Budget Plan (RAB), SPP, SPTB, APBDes Implementation Report.

\section{RESULTS AND DISCUSSION}

Analysis of village financial management through 5 stages of village financial management, namely: the planning, implementation, administration, reporting, and accountability stages with the principles of accountability and transparency.

\section{A. Planning Stage Analysis}

Based on the results of interviews, observation and documentation, it was found that the village financial management planning process was preceded by holding a village meeting to discuss the RPJMDes which was then poured into the RKPDes. From the RPJMDes, important programs will be selected which are agreed upon to be included in the RKPDes. From the RKPDes it is then outlined in the APBDes such as Village Original Income, Village Fund Allocation, Regional Assistance, Provincial Assistance, or Assistance from Third Parties. Even though the regional financial management planning has followed Permendagri No.113 / 2014, there is a statement from the village apparatus stating that the submission of the Village Regulation draft on APBDesa that has been agreed upon is not in accordance with the agreed schedule and deadline, which is no later than October. There are still some RKPDes programs that copy APBDes from other villages. The results of this study are in line with Faridah and Suryono [14], Irma [15], Romance [16], Wida and Ainul [17], Alfasadun et al [18] which shows that the management of village finances, especially ADD and APBDes, has been going well. At the planning stage, 5 villages in Amarasi Selatan District, Kupang Regency, NTT had met the principle of transparency, but not all of them had fulfilled the principle of accountability.

\section{B. Implementation Stage Analysis}

From the results of interviews, observations and documentation carried out by representatives of the management in several villages who participated in the village financial management process, it shows that the process of implementing village financial management is carried out by the Village Treasurer. The Village Treasurer regulates the administration of village revenues and expenditures related to activities in the village. In the implementation of Village activities / programs, first the executor of the activities, namely the Head / Kasi either Government, Economic Development, or Community Empowerment, must first submit an application and be approved by the Village Head regarding the Application for Disbursement of the village budget to be used for planned activities / programs. The results of this study are in line with Faridah and Suryono [14], Irma [15], Romance [16], Wida and Ainul [17], Alfasadun et al [18] which show that village financial management, especially ADD and APBDes, has gone well. and in accordance with existing regulations. At the implementation stage, 5 villages in Amarasi Selatan District, Kupang Regency, NTT have fulfilled the principle of transparency, but not all of them have fulfilled the principle of accountability.

\section{Administration Stage Analysis}

The results of interviews, observations and documentation carried out to representatives of the management in several villages who participated in the village financial management process showed that in the process of managing village finances, the village treasurer used general treasury books, tax books, and village bank books outside the revenue and expenditure budget books. village. Even though administration has followed Permendagri 113/2014, officials in several villages said that the process of submitting Village financial accountability reports to the Village Head each month did not comply with the predetermined schedule or deadline, namely no later than the 10th of the following month. In fact, the use of information technology which can help accelerate the reporting process is not yet optimal. At the administrative stage, 5 villages in Amarasi Selatan District, Kupang Regency, NTT had fulfilled the principle of transparency but had not fulfilled the principle of accountability.

\section{Reporting Analysis Stage}

The results of interviews, observations and documentation carried out on representatives of management in 5 villages in South Amarasi District who participated in the village financial management process showed that, in the village financial reporting process related to village financial income and expenditure, it was reported to the Kupang Regent through the Head of South Amarasi Sub-district. Even though the reporting has followed Permendagri 113/2014, some village officials said that in the process of submitting reports on the realization of the APBDesa implementation each semester and the year-end reports are still not in accordance with the predetermined schedule or deadline, namely the end of July and the end of January. Although the reporting has followed Permendagri $113 / 2014$, in the process of submitting reports on the realization of the APBDesa implementation each semester and year-end reports, it is still not in accordance with the predetermined schedule or deadline, namely the end of July and the end of January. This finding is in line with Article 27 of Law no. 4 of 2014 and Minister of Home Affairs Regulation No. 113/2014, that the Village Head is required to submit a village government administration report at the end of each 
fiscal year to the Regent. At the reporting stage, 5 villages in Amarasi Selatan Sub district, Kupang District, NTT had fulfilled the principle of transparency but had not fully fulfilled the principle of accountability.

\section{E. Analysis of the Accountability Stage}

The results of interviews, observations and documentation carried out on representatives of management in 5 villages in South Amarasi District who participate in the village financial management process show that in the process of village financial management accountability is carried out by each activity executing section, reporting the accountability of each activity to the Village Treasurer who is verified first by the Village Secretary who was then reported back by the Village Head to the Camat. Even though the accountability has followed Permendagri 113/2014, there are village officials who say that in the process of submitting the accountability report the realization of the APBDesa implementation is still not in accordance with the established Village regulations. The requirements referred to are APBDes, Village Medium Term Work Plans (RPJMDes), and Village Work Plans (RKDes). The results of this study are in line with Article 27 of Law no. 6 of 2014 that the village head is obliged to report the implementation of the village government to the regents and mayors. The village head also provides a written statement of government administration to the BPD at the end of each fiscal year and provides and disseminates written governance information to the village community at the end of each fiscal year. This finding is in line with Faridah \& Suryono (2015), Irma (2015), and Romance (2014) that the management of village finances, especially ADD and APBDes, has been running well, but the principle of accountability has gradually begun to be applied even though it is not yet perfect, but it has shown commitment. who are very strong to carry out their responsibilities in accordance with their capacity and position. In the accountability stage, 5 villages in Amarasi Selatan District, Kupang Regency, NTT have met the principle of transparency, but there are still 3 villages that have not fulfilled the principle of accountability

\section{CONCLUSION}

Based on the results of the analysis and discussion, it can be concluded that the management of village finances in 5 villages in Amarasi Selatan sub-district, Kupang Regency, has been implemented according to Minister of Home Affairs Regulation No. 113 of 2014. All villages have fulfilled the principle of transparency, but most villages have not fulfilled the principle of accountability. There are still some important notes related to village financial management that still need to be addressed to increase accountability for village financial management. The village government must pay attention to the priority programs needed by each village according to the RPJMDes, empower village income potential, and determine expenditure according to the needs of each village, not imitate other villages.

\section{REFERENCES}

[1] Law Number 6 of 2014 concerning villages.

[2] Minister of Home Affairs Regulation No. 20/2018 concerning Village Financial Management. Ministry of Home Affairs, Directorate General of Village Government Development.

[3] Minister of Home Affairs Regulation No. 113 of 2014 concerning Village Financial Management. Ministry of Home Affairs, Directorate General of Village Government Development.

[4] Government Regulation Number 43 of 2014 concerning Implementation Regulations of Law Number 6 of 2014 concerning Villages.

[5] A. Abdul and I. Muhamad, Regional Financial Management Yogyakarta: YKPN School of Management, 2012.

[6] M. Mardiasmo, Public Sector Accounting. Yogyakarta: Andi, 2009.

[7] A. Dwiyanto, Public Bureaucratic Reform in Indonesia. Yogyakarta: Gadjah Mada University Press, 2015.

[8] A. Subroto, Accountability of Village Fund Management with Case Study of Village Fund Allocation Management in Inner Villages of Tlogomulyo District, Temanggung Regency. Thesis, 2009.

[9] M. Muntahanah and M. Murdijaningsih, The Effectiveness of Financia Management for Village Fund Allocation in Somagede District, Banyumas Regency, 2013.

[10] R. Ramadan, Comparative Analysis of Bangsri Village Financial Management and Village Financial Management According to Ministe of Home Affairs Regulation 37 of 2007, 2014.

[11] Minister of Home Affairs Regulation No. 37 of 2007 on Guidelines for Village Financial Management. Ministry of Home Affairs, Directorate General of Village Government Development.

[12] I. Bastian, Public Sector Management Control Systems. Jakarta Salemba Empat, 2014.

[13] E. Zein, "The Effect of Good Governance and Government Accounting Standards on Financial Accountability with Organizational Commitmen as Moderation," Journal of Accounting and Financial Review, 2011.

[14] F. Faridah and B. Suryono, "Transparency and Accountability of Village Governments in Management of the Village Revenue and Expenditure Budget (APBDes)," Journal of Accounting Science and Research Surabaya: Indonesian College of Economics (STIESIA) Surabaya, 2015.

[15] A. Irma, "Accountability for Village Fund Allocation Managemen (ADD) in Dolo Selatan District, Sigi Regency," Journal. Palu: Tadulako University, 2015.

[16] P.A. Romance, Accountability of Village Fund Allocation Management in Panarukan Subdistrict, Situbondo District, 2014. Thesis. Jember: University of Jember, 2015.

[17] S.A. Wida, Accountability for Village Fund Allocation Managemen (ADD) in the Villages of Rogojampu District, Banyuwangi Regency. Thesis. Jember: University of Jember, 2016.

[18] A. Alfasadun, "Transparency and Accountability of Village Fund Management," Proceedings of SENDI_U, 2018. 